\title{
Ankyloblepharon-ectodermal defects-cleft lip/palate syndrome
}

INSERM

\section{Source}

INSERM. (1999). Orphanet: an online rare disease and orphan drug data base. Ankyloblepharon-ectodermal defects-cleft lip/palate syndrome. ORPHA:1071

Ankyloblepharon-ectodermal defects-cleft lip/palate (AEC) syndrome is an ectodermal dysplasia syndrome (see this term) with defining features of ankyloblepharon filiforme adnatum (AFA), ectodermal abnormalities and a cleft lip and/or palate. 